$40(2) \mid 2011$

Varia

México, 5 al 8 de julio de 2011

Coloquio Internacional: «En torno a la muerte. Ritos, prácticas, imágenes y discursos»

México, 5 al 8 de julio de 2011

Georges Lomné

(2) OpenEdition

Journals

Edición electrónica

URL: http://journals.openedition.org/bifea/1559

DOI: 10.4000/bifea.1559

ISSN: 2076-5827

Editor

Institut Français d'Études Andines

Edición impresa

Fecha de publicación: 1 agosto 2011

Paginación: 450-452

ISSN: 0303-7495

Referencia electrónica

Georges Lomné, « Coloquio Internacional: «En torno a la muerte. Ritos, prácticas, imágenes y

discursos» », Bulletin de l'Institut français d'études andines [En línea], 40 (2) | 2011, Publicado el 01

febrero 2012, consultado el 07 noviembre 2020. URL : http://journals.openedition.org/bifea/1559 ;

DOI : https://doi.org/10.4000/bifea.1559

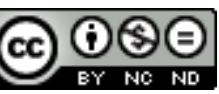

Les contenus du Bulletin de l'Institut français d'études andines sont mis à disposition selon les termes de la licence Creative Commons Attribution - Pas d'Utilisation Commerciale - Pas de Modification 4.0 International. 
Évènements

\section{COLOQUIO INTERNACIONAL: «EN TORNO A LA MUERTE. RITOS, PRÁCTICAS, IMÁGENES Y DISCURSOS»}

\section{México, 5 al 8 de julio de 2011}

In memoriam, Elsa Malvido Miranda (1941-2011)

Este magno coloquio tuvo lugar del martes 5 al viernes 8 de julio en los auditorios del Museo Nacional de Antropología de la ciudad de México. Fue convocado por el Centro de Estudios Mexicanos y Centroamericanos (CEMCA, UMIFRE 16, CNRS-MAEE) y la Dirección de Estudios Históricos del Instituto Nacional de Antropología e Historia (INAH-DEH) de México. Coordinado por Nadine Béligand (CEMCA) y Elsa Malvido Miranda (INAH-DEH), este evento logró reunir a 63 conferencistas y moderadores de 9 países. Contó con el auspicio de numerosas entidades científicas mexicanas, norteamericanas y francesas, entre las cuales el IFEA.

La idea del evento surgió a inicios de 2010 en ocasión de la publicación del n. 58 de la revista Trace, dedicado a «Las ciencias sociales y la muerte», bajo la dirección de Nadine Béligand. En esa edición, se presentó un enfoque pluridisciplinario para el establecimiento de comparaciones entre los cementerios de Francia, México y Nápoles y algunas prácticas en torno a la muerte que se estilan en el África subsahariana, París y Buenos Aires. Elsa Malvido Miranda y Nadine Béligand desearon entonces prolongar este primer esfuerzo a través de un coloquio internacional que permitiera abarcar épocas más remotas, anteriores a la época moderna (siglos XVI-XIX), y espacios más amplios, que incluyeran al Mediano y Extremo Oriente.

De entrada, en nombre del Comité científico, Delphine Mercier (CEMCA), Inés Herrera Canales (INAH-DEH) y Nadine Béligand (CEMCA) quisieron rendirle un sentido homenaje a Elsa Malvido Miranda, fallecida dos meses antes del coloquio, el 8 de abril. Elsa Malvido, después de haber consagrado 39 años de su vida al estudio de la historia de las enfermedades en México, les brindó un tributo muy cruel con su propio deceso. Por ende, cabe

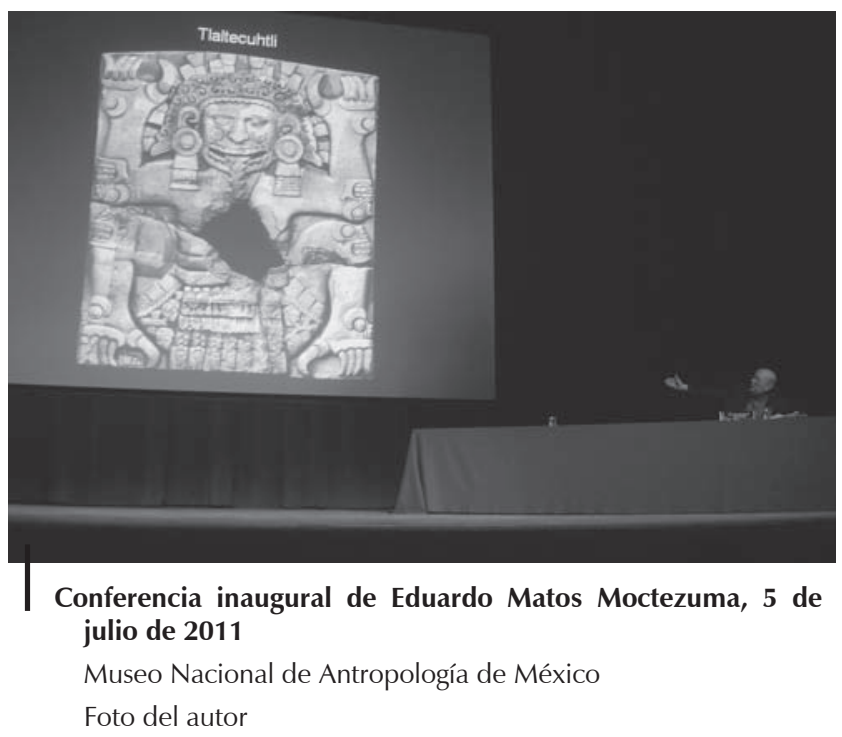
señalar la profunda emoción que su partida suscitó en todos los participantes: sus últimos esfuerzos los había consumido en la coorganización de este coloquio. 
Nadine Béligand enfatizó — a la par- el espíritu crítico, la valentía y el entusiasmo extremo de Elsa Malvido. En la evocación de su trayectoria científica, hizo especial mención del «Seminario de estudios sobre la muerte», cuya coordinación en el Departamento de Estudios Históricos del INAH estuvo a cargo de la historiadora mexicana, quién le dio un alcance nacional al proyectarlo muchas ciudades del país.

Asimismo, en una conferencia inaugural, Eduardo Matos Moctezuma, investigador emérito del INAH, se consagró al tema de «la muerte entre los mexicas: expresión particular de una realidad universal». Conocido desde 1975, gracias a su libro Muerte a filo de obsidiana: los nahuas frente a la muerte, el famoso arqueólogo del Templo Mayor y de Teotihuacán, disertó sobre las posibles correspondencias entre las representaciones del inframundo en el México antiguo y en Europa. Luego, contrastó los principales lugares de la muerte que establecieron los nahuas: el Omeyocán, regido por el sol y reservado a los guerreros, cautivos sacrificados y mujeres fallecidas durante el parto; el Tlalocán, paraíso de Tláloc reservado para quienes habían muerto por efecto del agua; y el Mictlán, inframundo regido por la horrorosa figura del dios Mictlantecuhtli para los que habían fallecido por muerte natural. El coloquio contó con 10 sesiones sucesivas, que resultaría vano intentar resumir en unas pocas líneas. Las temáticas fueron: 1- Los lugares de los muertos; 2- Rituales de sepultura; 3- Los cementerios; 4- Las ceremonias funerarias, el cuerpo y el martirio; 5- El servicio fúnebre; 6- Las representaciones del más allá; 7Enfermedad y muerte; 8- Circulación de las creencias y de los rituales; 9- Rituales funerarios; 10- Vida y muerte: vivos entre muertos.

Cabe felicitarse de un encuentro académico que permitió el diálogo entre especialistas de la muerte, provenientes de variadas disciplinas, en el que se abordaron áreas culturales y períodos muy diversos. Es así como Philippe Chambon (CNRS), arqueólogo de las primeras necrópolis de la Europa occidental pudo exponer sus hallazgos a sus colegas mexicanistas: Grégory Pereira (CEMCA) y Ximena Chávez Balderas (INAH). Ann Carol (Universidad de Aix-Marseille I), estudiosa de los cuerpos de los guillotinados en la Francia del siglo XIX, pudo dialogar con Nathalie Kouamé (INALCO, París III-Sorbona), especialista en el tema de los mártires de Nagasaki (1597). Fue notable descubrir que unos jóvenes mexicanos, harto talentosos, habían tenido la audacia de investigar sobre mundos muy ajenos a los suyos: Alejandra Gómez Colorado (Museo Nacional de las Culturas, México D.F.) nos habló acerca de la ceremonia del Ashura en Teherán y María Fernanda Vásquez Vela (El Colegio de México) disertó sobre el martirio en la historia sikh.

Este coloquio se mantendrá en el recuerdo gracias a que, en breve, el Cemca y el INAH, en asociación con la Universidad de Lyon-II y el IFEA publicarán las actas de este apasionante balance sobre la universalidad y las singularidades de las actitudes frente a la muerte: el mejor de los homenajes que Elsa Malvido Miranda haya podido tener. 